\title{
Climatic variability and its characterisation over Punjab, India
}

\section{P. K. KINGRA ${ }^{1}$, RAJ SETIA ${ }^{2 *}$, SIMRANJEET SINGH ${ }^{2}$, JATINDER KAUR ${ }^{1}$, SATINDER KAUR ${ }^{1}$, SOM PAL SINGH ${ }^{1}$, S. S. KUKAL ${ }^{3}$ and BRIJENDRA PATERIYA ${ }^{2}$}

\author{
${ }^{1}$ School of Climate Change and Agricultural Meteorology, Punjab Agricultural University, Ludhiana \\ ${ }^{2}$ Punjab Remote Sensing Centre, Ludhiana \\ ${ }^{3}$ College of Agriculture, Punjab Agricultural University, Ludhiana \\ email:pkkingra@pau.edu
}

\begin{abstract}
The climate data (maximum temperature, minimum temperature and rainfall) of forty year (19742013) was analysed for kharif (May to October) and rabi (November to April) seasons in Punjab, India. The non-parametric Mann-Kendall and Sen's methods were used to determine trend (positive or negative) in climate data over a period of 40 years. A decrease in rainfall and increase in temperature from northeast to south-west Punjab during both the kharif and rabi seasons was observed. No significant temporal variation was observed in maximum temperature and rainfall during both the seasons, but a significant increase in minimum temperature over the years was observed in different zones of Punjab. On an average, minimum temperature is increasing at $0.05^{\circ} \mathrm{C}$ per year during both the seasons.
\end{abstract}

Key words: Climatic variability, GIS, Mann-Kendall test, Punjab

Climate change is one of the most prominent global environmental issues. During the period from 1885 to 2012 , the mean global temperature has increased by $0.85^{\circ} \mathrm{C}$ and is predicted to increase further by $1.6-5.8^{\circ} \mathrm{C}$ by the end of $21^{\text {st }}$ century (IPCC, 2014). Developing countries are more vulnerable to such changes as they have limited resources to cope up with the disasters and agriculture plays dominant role in their national economy (Majumder et al, 2016). The northern part of Indian sub-continent has been placed under high risk zone for heat stress risks in view of future climate change scenarios (Teixeira et al 2013). Under such conditions, the sustainability of natural resources and food security for the burgeoning population in the region is at stake.

The Punjab state is also experiencing large fluctuations in temperature and precipitation patterns every year leading to large oscillations in agricultural productivity in the region. The abnormal weather conditions have already started taking a toll on productivity of wheat crop during last 5-6 years. To manage this alarming situation, there is a need to analyse the spatio-temporal variability of climatic conditions at regional scale so that viable mitigation / adaptation strategies could be developed and implemented on regional basis. Keeping this in view, the spatio-temporal climatic variability during kharif and rabi seasons has been studied for three different agroclimatic regions viz. Northeast, central and south-west Punjab by using statistical procedures.

\section{MATERIALS AND METHODS}

\section{Study area}

The study was conducted for Punjab state with latitudinal extent of $29^{\circ} 30^{\prime} \mathrm{N}$ to $32^{\circ} 32^{\prime} \mathrm{N}$, longitudinal extent of $73^{\circ} 55^{\prime} \mathrm{E}$ to $76^{\circ} 50^{\prime} \mathrm{E}$, elevation of 230 to $260 \mathrm{mAMSL}$ and representing transgangetic agroclimatic region of India. As there is a large climatic variability from north-east to southwest region, so the state was divided into three agroclimatic regions involving different districts as mentioned below:

1. North-east region- Gurdaspur, Hoshiarpur and Roopnagar

2. Central region- Amritsar, Jalandhar, Kapurthala, Ludhiana, Patiala and Sangrur

3. South-west region- Bathinda, Faridkot and Ferozepur

Data collection and analysis

The monthly data of maximum temperature, minimum temperature and rainfall for different locations of Punjab was collected from various sources (like Agrometeorological Observatory, School of Climate Change and Agricultural Meteorology, Punjab Agricultutral University (PAU), Ludhiana; different regional research stations of PAU, India Meteorological Department (Chandigarh) and Statistical Abstracts of Punjab) of 40 years (1974-75 to 2013-14).

\section{Temporal variability analysis}

The data was analysed for two major cropping seasons 
Table 1: Results of the statistical tests for maximum temperature during kharif and rabi seasons over the period 1974-75 to 2013-14

\begin{tabular}{|c|c|c|c|c|c|c|}
\hline Zone & $\begin{array}{l}\mathrm{T}_{\max }\left({ }^{\circ} \mathrm{C}\right) \\
/ \text { Test }\end{array}$ & $\begin{array}{l}1974-75 \text { to } \\
1983-84\end{array}$ & $\begin{array}{l}1984-85 \text { to } \\
1993-94\end{array}$ & $\begin{array}{l}1994-95 \text { to } \\
2003-04\end{array}$ & $\begin{array}{l}2004-05 \text { to } \\
2013-14\end{array}$ & $\begin{array}{l}1974-75 \text { to } \\
2013-14\end{array}$ \\
\hline \multicolumn{7}{|c|}{ Kharifseason (May - October) } \\
\hline \multirow[t]{3}{*}{ North-east } & $\mathrm{Mean}+\mathrm{SD}$ & $32.9 \pm 0.4$ & $33.0 \pm 0.5$ & $32.9 \pm 0.5$ & $33.1 \pm 0.6$ & $32.8 \pm 0.2$ \\
\hline & Z & -0.358 & 0.000 & 0.716 & 1.252 & 0.478 \\
\hline & Q & -0.044 & 0.004 & 0.031 & 0.184 & 0.005 \\
\hline \multirow[t]{3}{*}{ Central } & $\mathrm{Mean}+\mathrm{SD}$ & $34.9 \pm 0.9$ & $34.9 \pm 0.9$ & $34.8 \pm 0.9$ & $34.9 \pm 0.6$ & $34.9 \pm 0.7$ \\
\hline & Z & -0.358 & 0.358 & 1.252 & $1.789+$ & 0.000 \\
\hline & Q & -0.037 & 0.009 & 0.039 & 0.012 & 0.000 \\
\hline \multirow[t]{3}{*}{ South-West } & $\mathrm{Mean}+\mathrm{SD}$ & $36.0 \pm 0.1$ & $36.1 \pm 0.1$ & $35.9 \pm 0.1$ & $36.6 \pm 0.4$ & $35.9 \pm 0.1$ \\
\hline & Z & -0.179 & 0.000 & 0.179 & -0.537 & -1.596 \\
\hline & Q & -0.027 & 0.018 & 0.036 & -0.040 & -0.015 \\
\hline \multicolumn{7}{|c|}{ Rabi season (November - April) } \\
\hline \multirow[t]{3}{*}{ North-east } & Mean+SD & $22.6 \pm 0.5$ & $23.0 \pm 0.5$ & $23.1 \pm 0.5$ & $24.3 \pm 0.9$ & $23.2 \pm 0.6$ \\
\hline & Z & $-1.968 *$ & -0.716 & 1.073 & 0.537 & $2.645^{* *}$ \\
\hline & Q & -0.187 & -0.045 & 0.124 & 0.091 & 0.034 \\
\hline \multirow[t]{3}{*}{ Central } & $\mathrm{Mean}+\mathrm{SD}$ & $24.3 \pm 0.9$ & $24.7 \pm 0.9$ & $24.8 \pm 1.0$ & $25.0 \pm 0.3$ & $24.7 \pm 0.7$ \\
\hline & Z & $-1.789+$ & -0.537 & 0.716 & -0.358 & $2.086^{*}$ \\
\hline & Q & -0.203 & -0.077 & 0.119 & -0.067 & 0.022 \\
\hline \multirow[t]{3}{*}{ South-West } & $\mathrm{Mean}+\mathrm{SD}$ & $25.7 \pm 0.8$ & $26.3 \pm 0.7$ & $26.2+0.8$ & $25.4+0.1$ & $25.9 \pm 1.0$ \\
\hline & Z & $-1.968 *$ & -0.716 & 0.894 & $-1.968 *$ & -1.456 \\
\hline & Q & -0.181 & -0.079 & 0.093 & -0.362 & -0.019 \\
\hline
\end{tabular}

Z: Mann-Kendall test, Q: Sen's slope estimator; ${ }^{*} \mathrm{~N}$ Statistically significant trends at the $5 \%$ significance level, ** Statistically significant trends at the $1 \%$ significance level, ${ }^{* * *}$ Statistically significant trends at the $0.1 \%$ significance level

in Punjab: kharif (May to October) and rabi (November to April) (Kaur et al 2006). The decadal averages and standard deviations in maximum and minimum temperatures and rainfall were calculated separately for kharif and rabi seasons, apart from the overall of averages and standard deviations during the period 1974-2013 for both kharif and rabi seasons. In this study, two non-parametric statistical tests (Mann-Kendall and Sen's slope estimator) were used to detect the meteorological variables' trends (Meals et al., 2011).

\section{RESULTS AND DISCUSSION}

\section{Maximum temperature}

Among the three zones, maximum temperature was highest in the south-west zone followed by central and north-east zone (Table 1). The decadal variation in different zones of Punjab showed an increase in rabi season maximum temperature in north-eastern and central Punjab from first decade (1974-83) to fourth decade (1984-2013), but it increased from first decade (1974-83) to third decade (19841993 ) in the south-western zone and then decreased from third decade (1984-1993) to fourth decade (2004-13). The maximum temperature increased from 22.6 to $24.3^{\circ} \mathrm{C}$ in the north-eastern zone, from 24.3 to $25.0^{\circ} \mathrm{C}$ in the central Punjab, whereas in the south-western region it increased from 25.7 to $26.3^{\circ} \mathrm{C}$ from $1974-83$ to $1984-93$, but decreased thereafter to $25.4^{\circ} \mathrm{C}$ during $2004-13$.

The MK Z-values of maximum temperature were not significant during kharif season in all the three regions of Punjab but it decreased significantly during rabi season in the first decade (1974-75 to 1983-84) in north-east ($0.187^{\circ} \mathrm{C}$ year $\left.{ }^{-1}\right)$ and south-west regions $\left(-0.181^{\circ} \mathrm{C}_{\text {year }}{ }^{-1}\right)$. The change in maximum temperature from 1983-84 to 2013 14 was variable (Table 1), however maximum temperature has significantly increased during rabi season in north-east 
Table 2: Results of the statistical tests for minimum temperature during kharif and rabi seasons over the period 1974-75 to 2013-14

\begin{tabular}{|c|c|c|c|c|c|c|}
\hline Zone & $\begin{array}{l}\mathrm{T}_{\text {min }}\left({ }^{\circ} \mathrm{C}\right) / \\
\text { Test }\end{array}$ & $\begin{array}{l}1974-75 \text { to } \\
1983-84\end{array}$ & $\begin{array}{l}1984-85 \text { to } \\
1993-94\end{array}$ & $\begin{array}{l}1994-95 \text { to } \\
2003-04\end{array}$ & $\begin{array}{l}2004-05 \text { to } \\
2013-14\end{array}$ & $\begin{array}{l}1974-75 \text { to } \\
2013-14\end{array}$ \\
\hline \multicolumn{7}{|c|}{ Kharif season (May - October) } \\
\hline \multirow[t]{3}{*}{ North-east } & Mean \pm SD & $20.7 \pm 0.5$ & $20.8 \pm 0.5$ & $21.3 \pm 0.4$ & $22.9 \pm 0.8$ & $21.5 \pm 0.8$ \\
\hline & Z & 0.000 & -0.179 & 0.894 & $1.789+$ & $4.509 * * *$ \\
\hline & Q & 0.003 & -0.010 & 0.062 & 0.350 & 0.044 \\
\hline \multirow[t]{3}{*}{ Central } & Mean + SD & $22.3 \pm 0.4$ & $22.4 \pm 0.6$ & $22.8 \pm 0.5$ & $23.6 \pm 0.4$ & $22.8 \pm 0.5$ \\
\hline & Z & 1.073 & 0.716 & $1.968^{*}$ & $2.326^{*}$ & $5.604 * * *$ \\
\hline & Q & 0.061 & 0.044 & 0.100 & 0.154 & 0.051 \\
\hline \multirow[t]{3}{*}{ South-West } & $\mathrm{Mean}+\mathrm{SD}$ & $22.9 \pm 0.1$ & $23.2 \pm 0.1$ & $23.5 \pm 0.1$ & $24.2 \pm 0.3$ & $23.4 \pm 0.2$ \\
\hline & Z & 0.358 & 0.358 & 1.252 & $1.968^{*}$ & $5.138 * * *$ \\
\hline & Q & 0.041 & 0.001 & 0.077 & 0.154 & 0.047 \\
\hline \multicolumn{7}{|c|}{ Rabi season (November - April) } \\
\hline \multirow[t]{3}{*}{ North-east } & Mean+SD & $8.5 \pm 0.4$ & $8.8 \pm 0.5$ & $9.2 \pm 0.5$ & $10.4 \pm 0.5$ & $9.1 \pm 0.2$ \\
\hline & Z & 0.000 & 0.000 & $1.968^{*}$ & 0.894 & $4.742 * * *$ \\
\hline & Q & 0.007 & -0.003 & 0.110 & 0.266 & 0.052 \\
\hline \multirow[t]{3}{*}{ Central } & Mean+SD & $9.3 \pm 0.4$ & $9.5 \pm 0.8$ & $10.0 \pm 0.5$ & $10.4 \pm 0.6$ & $9.7 \pm 0.6$ \\
\hline & Z & 1.252 & 0.000 & $2.862 * *$ & -0.358 & $4.276 * * *$ \\
\hline & Q & 0.133 & 0.039 & 0.189 & -0.065 & 0.046 \\
\hline \multirow[t]{3}{*}{ South-West } & $\mathrm{Mean}+\mathrm{SD}$ & $9.6 \pm 0.1$ & $10.0 \pm 0.2$ & $10.3 \pm 0.2$ & $10.8 \pm 0.5$ & $10.0 \pm 0.3$ \\
\hline & Z & 0.716 & 0.000 & 1.610 & 0.179 & $4.602 * * *$ \\
\hline & Q & 0.043 & 0.000 & 0.117 & 0.070 & 0.047 \\
\hline
\end{tabular}

Z: Mann-Kendall test, Q: Sen's slope estimator; * Statistically significant trends at the $5 \%$ significance level, **Statistically significant trends at the $1 \%$ significance level, ${ }^{* * *}$ Statistically significant trends at the $0.1 \%$ significance level

$\left(0.034^{\circ} \mathrm{C}\right.$ year $\left.{ }^{-1}\right)$ and central regions $\left(0.022^{\circ} \mathrm{C}\right.$ year $\left.{ }^{-1}\right)$ of Punjab over a period of 40 years (Table 1 ).

\section{Minimum temperature}

The mean long-term (1974-2013) minimum temperature during $\mathrm{rabi}$ season was $9.1 \pm 0.2^{\circ} \mathrm{C}$ in north-east, $9.7 \pm 0.6^{\circ} \mathrm{C}$ in central and $10.0 \pm 0.3^{\circ} \mathrm{C}$ in south-western zones of Punjab (Table 2). The decadal analysis indicated that mean minimum temperature during rabi season increased from 8.5 to $10.4^{\circ} \mathrm{C}$ in north-east, 9.3 to $10.4^{\circ} \mathrm{C}$ in central and 9.6 to $10.8^{\circ} \mathrm{C}$ in the south-western zones of Punjab. The MK $\mathrm{Z}$-values of minimum temperature indicated a significant shift from the normal. During kharif season, the rate of increase in minimum temperature was $0.044^{\circ} \mathrm{C}$ year ${ }^{1}$ in north-east regions, $0.051{ }^{\circ} \mathrm{C}$ per year in central region and $0.047^{\circ} \mathrm{C}$ year ${ }^{1}$ in south-west. During rabi season, the rate of increase was $0.052^{\circ} \mathrm{C}$ year ${ }^{1}$ in north-east regions, $0.046^{\circ} \mathrm{C}$ per year in central region and $0.047^{\circ} \mathrm{C}$ year ${ }^{1}$ in south-west.
Decade-wise analysis during kharif season indicated significant increase in the central region $\left(0.100^{\circ} \mathrm{C}_{\text {year }}{ }^{-1}\right)$ from $1994-95$ to $2003-04$ and also in the south-west $\left(0.154^{\circ} \mathrm{C}\right.$ year $\left.{ }^{-1}\right)$ and central regions $\left(0.154^{\circ} \mathrm{C}_{\text {year }}{ }^{-1}\right)$ from $2004-05$ to 2013-14. During rabi season, significant increase in minimum temperature was observed in north-east $\left(0.110^{\circ} \mathrm{C}_{\text {year }}{ }^{-1}\right)$ and central plain region $\left(0.189^{\circ} \mathrm{C}_{\text {year }}{ }^{-1}\right)$ from $1994-95$ to 2003-04 (Table 2).

\section{Rainfall}

The average long-term (1974 to 2013) kharif season rainfall was $790 \pm 52.2 \mathrm{~mm}$ in north-east, $581 \pm 120 \mathrm{~mm}$ in central and $306 \pm 119 \mathrm{~mm}$ in south-western zones of Punjab (Table 3). The decadal pattern of rainfall in different zones showed that kharif season rainfall increased from $692.6 \mathrm{~mm}$ during 1974-83 to $891.4 \mathrm{~mm}$ during 1994-2003, but decreased to $794.2 \mathrm{~mm}$ during 2004-13 in the north-eastern 
Table 3: Results of the statistical tests for rainfall during kharif and rabi seasons over the period 1974-75 to 2013-14

\begin{tabular}{|c|c|c|c|c|c|c|}
\hline Zone & $\begin{array}{l}\text { Rainfall(mm) } \\
\text { / Test }\end{array}$ & $\begin{array}{l}1974-75 \text { to } \\
1983-84\end{array}$ & $\begin{array}{l}1984-85 \text { to } \\
1993-94\end{array}$ & $\begin{array}{l}1994-95 \text { to } \\
2003-04\end{array}$ & $\begin{array}{l}2004-05 \text { to } \\
2013-14\end{array}$ & $\begin{array}{l}1974-75 \text { to } \\
2013-14\end{array}$ \\
\hline \multicolumn{7}{|c|}{ Kharifseason (May - October) } \\
\hline \multirow[t]{3}{*}{ North-east } & $\mathrm{Mean} \pm \mathrm{SD}$ & $693 \pm 59.5$ & $780 \pm 63.9$ & $891 \pm 80.5$ & $794 \pm 58.7$ & $790 \pm 52.2$ \\
\hline & $\mathrm{Z}$ & -0.358 & -0.358 & $-2.326^{*}$ & -0.537 & 0.664 \\
\hline & Q & -2.414 & -2.718 & -9.452 & -1.711 & 0.194 \\
\hline \multirow[t]{3}{*}{ Central } & Mean+SD & $501 \pm 124$ & $556 \pm 160$ & $664 \pm 118$ & $605 \pm 95.7$ & $581 \pm 120.1$ \\
\hline & $\mathrm{Z}$ & 0.000 & -0.358 & 0.179 & -0.358 & 0.944 \\
\hline & Q & -0.017 & -3.007 & 0.926 & -2.423 & 0.408 \\
\hline \multirow[t]{3}{*}{ South-West } & Mean \pm SD & $281 \pm 101$ & $314 \pm 134$ & $321 \pm 136$ & $307 \pm 123$ & $306 \pm 119$ \\
\hline & $\mathrm{Z}$ & -1.252 & -0.537 & -1.431 & 0.716 & 0.618 \\
\hline & Q & -3.992 & -1.408 & -4.051 & 3.900 & 0.261 \\
\hline \multicolumn{7}{|c|}{ Rabi season (November - April) } \\
\hline \multirow[t]{3}{*}{ North-east } & $\mathrm{Mean} \_\mathrm{SD}$ & $222+43.9$ & $162+37.3$ & $166+34.2$ & $141 \pm 35.4$ & $173 \pm 79.3$ \\
\hline & $\mathrm{Z}$ & $2.683 * *$ & 0.537 & -0.537 & 0.179 & -1.130 \\
\hline & Q & 4.985 & 0.900 & -1.270 & 0.232 & -0.193 \\
\hline \multirow[t]{3}{*}{ Central } & $\mathrm{Mean} \_\mathrm{SD}$ & $158+44.6$ & $109 \pm 38.2$ & $118+29.1$ & $97.9 \pm 31.8$ & $121 \pm 33.3$ \\
\hline & $\mathrm{Z}$ & $3.578 * * *$ & 0.179 & -0.894 & -0.179 & -1.247 \\
\hline & Q & 4.724 & 0.194 & -0.418 & -0.366 & -0.130 \\
\hline \multirow[t]{3}{*}{ South-West } & $\mathrm{Mean} \pm \mathrm{SD}$ & $84.7 \pm 6.9$ & $63.4 \pm 8.8$ & $67.8 \pm 7.9$ & $52.5 \pm 10.6$ & $67.1 \pm 5.5$ \\
\hline & $\mathrm{Z}$ & $2.504 *$ & 0.000 & -0.894 & 0.358 & -0.711 \\
\hline & Q & 1.762 & 0.022 & -0.282 & 0.133 & -0.058 \\
\hline
\end{tabular}

Z: Mann-Kendall test, Q: Sen's slope estimator; *Statistically significant trends at the $5 \%$ significance level, **Statistically significant trends at the $1 \%$ significance level, ${ }^{* *}$ Statistically significant trends at the $0.1 \%$ significance level

zone. However, in central zone the annual rainfall varied from $501 \mathrm{~mm}$ during 1974-83 to $664 \mathrm{~mm}$ during 1994-2003, but again decreased to $605 \mathrm{~mm}$ during 2004-13. In southwest zone, it varied from $281 \mathrm{~mm}$ during $1974-83$ to $321 \mathrm{~mm}$ during 1994-2003 and then again decreased to $306.9 \mathrm{~mm}$ during 2004-13. The average kharif season rainfall in the state increased from $493 \mathrm{~m}$ during $1974-83$ to $633 \mathrm{~mm}$ during 1994-2003 and then decreased to $576 \mathrm{~mm}$ during 2004-13. However, in all the cases there was an increase in rainfall compared to the first decade.

The average rainfall during rabi season was highest in north-eastern region $(173+79.3 \mathrm{~mm})$ followed by central $(121 \pm 33.3 \mathrm{~mm})$ and south-western $(67.1 \pm 5.5 \mathrm{~mm})$ zones. There was no consistent pattern of change in rainfall over different decades in the three zones of Punjab (Table 3 ). The lower Mann-Kendall's Z values indicated highly variable and erratic nature of rainfall in the region. In general, trend in rainfall over 40 years showed that it increased during kharif season but decreased during rabi season. during rabi season, significant increase in rainfall was from 1974-75 to 1983-84 and the rate of increase was $4.985 \mathrm{~mm}_{\text {year }}{ }^{-1}$ $(Z=2.683)$ in north-east, $4.728 \mathrm{~mm} \mathrm{year}^{-1}(Z=3.578)$ in central and $1.762 \mathrm{~mm}$ year $^{-1}(Z=2.504)$ in south-west region (Table 3).

\section{CONCLUSIONS}

There is a significant decrease in rainfall and increase in temperature from north-east to south-western Punjab but no significant temporal variability trend was observed in maximum temperature and rainfall in the state. However, significant increase in minimum temperature has been observed in different zones of Punjab.

\section{REFERENCES}

IPCC. (2014). Summary for policymakers pp.1-32. In: C. B. Barros, V. R. Dokken, D. J. Mach, K. J. Mastrandrea, M. D. Bili, T. E. Chatterjee, K. L. M. Ebi, Y. O. Estrada, R. 
C. Genova, B. Girma, E. S. Kissel, A. N. Levy, S. MacCracken, P. R. Mastrandrea \& L. L. White (2014.), Summary for policymakers: Climate Change Impacts, Adaptation, and VulneRability. Part A: Global and Sectoral Aspects. Contribution of Working Group II Fifth Assessment Report of the Intergovernmental Panel on Climate Change Cambridge University Press, Cambridge, United Kingdom and New York, NY, USA.

Kaur, P., Singh, H. and Hundal S S. (2006). Annual and seasonal climatic variabilities at Ludhiana, Punjab. J. Agric. Phys. 6(1): 39-45.
Majumder, D., Kingra, P. K., and Singh, S. P. (2016). Climate variability impact on water requirement of spring maize in central and sub-mountainous Punjab. Annals Agric. Res. 37: 1-6.

Meals, D. W., Spooner, J., Dressing S A. and Harcum, J. B. (2011). "Statistical analysis for monotonic trends", Tech Notes 6, Developed for U.S. Environmental Protection AgencyTetra Tech, Inc., Fairfax, VA, 23 p

Teixeira, E. I., Fischer, G., Velthuizen, H. V., Walter, C. and Ewert, F. (2013). Global hotspots of heat stress on agricultural crops due to climate change. Agric. Forest Meteorol., 170: 206-215. 